\title{
Gnathic Osteosarcoma: A Retrospective Analysis over a 20 Year Period \\ Prabhu $\mathrm{S},{ }^{1}$ Jose $\mathrm{M},{ }^{1}$ Iyengar $\mathrm{S}^{2}$
}

${ }^{1}$ Department of Oral Pathology

Yenepoya Dental College

Yenepoya University

Mangalore

${ }^{2}$ Department of Oral Pathology

SDM College of Dental Sciences

Dharwad

\section{Corresponding Author}

Sudeendra Prabhu

Department of Oral Pathology

Yenepoya Dental College

Yenepoya University

Mangalore, Karnataka

India

Email: drsudi78@yahoo.co.in

Citation

Prabhu S, Jose M, Iyengar S. Gnathic Osteosarcoma: A Retrospective Analysis over a 20 Year Period. Kathmandu Univ Med J 2013;41(1):37-40.

\section{ABSTRACT \\ Background}

Osteosarcomas are very rare malignant mesenchymal neoplasms affecting jaw bones. Only few studies are reported about this lesion in this particular region.

\section{Objective}

We wanted to assess the demography and tumor behaviour and histopathological pattern, retrospectively in the available cases.

\section{Methods}

A retrospective analysis of hospital records for 20 years was carried out. Clinical features, radiographic findings, histopathological details and treatment aspect of each of the lesions was considered.

\section{Results}

Findings of this study revealed only 13 cases of gnathic osteosarcomas, usually occurring in middle age, with equal sex predilection and predominantly seen in maxilla. Histopathologically, most of them belonged to osteogenic variant.

\section{Conclusion}

Only few cases of gnathic osteosarcomas are reported in this region mainly in the young males. Interestingly many of them has history of dental extraction before the onset of disease.

\section{KEY WORDS}

Demography, osteosarcoma, retrospective analysis 


\section{INTRODUCTION}

Osteosarcomas (OS) are tumors associated with bone which are characterized by the direct formation of bone/ osteoid by tumor cells. ${ }^{1}$ OS of jaw bones is very rare and it comprises of only $6.5 \%$ of total OS as a whole. ${ }^{2}$ Demographics and behaviour of OS are completely different compared to classic OS of long bones. ${ }^{3}$ The demographic data of OS varies in different population..$^{4-9}$ We wanted to assess the clinico-pathologic correlation of OS in Indians and correlate with other races.

\section{METHODS}

The case files of patients histologically diagnosed to have an osteosarcoma treated in SDM College of Dental Sciences, Dharwad, Karnataka, India, from 1990 to 2010, were retrieved and information about these lesions was documented. The sample involves all the cases reported to the hospital. The clinical parameters included are age, sex, location, duration, family history, associated symptoms and behavior of the lesion. The radiographic appearance, histological features, treatment and follow up data were also recorded.

\section{RESULTS}

A total of 13 cases of osteosarcomas were recorded over the last twenty years period. In general, the age ranged from 4.5 to 70 years with mean age of 36.42 years (Fig 1). The male:female ratio for these patients was 1.1:1 with slight male predilection (seven men and six women]. Among all the patients, lesion reported was solitary. Most of the time, these individuals complained of a slow growing swelling of the jaws and facial asymmetry. The average duration of the swelling was 4.8 months with least being 15 days and the longest being two years. In one case, a small swelling was present since three years and it started just after extraction of a tooth. But its growth was rapid for last six months. None of these cases had any family history of similar lesions. However, interestingly four of these patients (30\%) had a history of extraction of the tooth in the same location. One each of the patients had a history of retinoblastoma in the same region, anti-tubercular drug and radiotherapy.

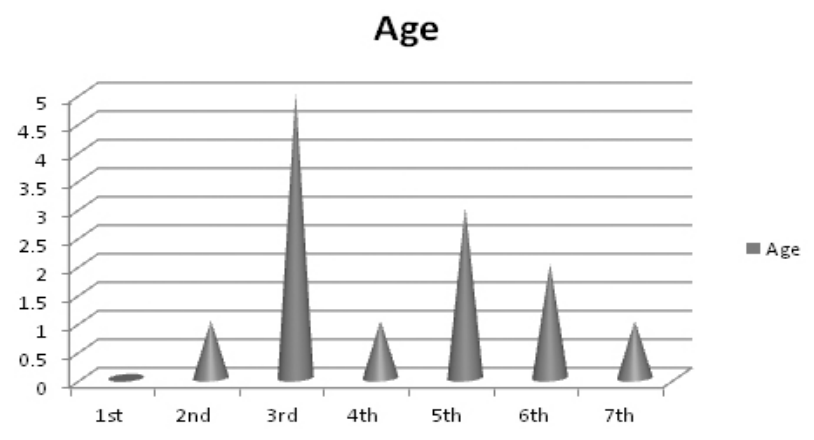

Figure 1. Age distribution (in decades) of osteosarcomas.
Majority of them mentioned paresthesia (four cases), bleeding from nose (two cases), restricted mouth opening (one cases), and mobility of teeth (two cases) as associated symptoms. On palpation nine of them were firm and tender, three being firm but non tender and only one was soft. Among these, one lesion was pulsatile which mislead the clinicians in terms of a vascular lesion. Six of the cases showed lymph node enlargement, all of them in the submandibular region. In addition one among these showing enlarged node in the axillary and one in the jugulo digastric region.

Smallest among all the lesions was of $2 \times 2 \mathrm{cms}$ and largest being $6 \times 8 \mathrm{cms}$, average being $3 \times 8 \mathrm{cms}$. If we take site into consideration, there was definite predilection for maxilla (46\%) compared to mandible (30\%), where as few of the lesions appeared in both the jaws (23\%).

Radiographically, most of them had a mixed opaque and lucent picture with diffuse borders with expansion of cortical plate in seven of the swellings. Extention into the max sinus (three), orbit (two), naso-ethmoidal sinus (one) and zygomatic complex (one) was also evident on the $x$ ray. Among all the lesions affecting the mandible, only two showed involvement of lower border of mandible (Table 1).

Clinically, provisional diagnosis of osteosarcoma was considered only on five occasions (36\%), where as four times (31\%), it was a fibro-osseous lesion. Clinical diagnosis of vascular lesion, recurrent retinoblastoma, carcinoma and peripheral giant cell granuloma [vestibule], was also a consideration in the remaining cases.

Tumor cells were plump, round to ovoid or spindle shaped with marked cellular atypia, hyper chromatism and pleomorphism and most of the time, the nucleus was vesicular. Tumor cells were dispersed in between the osteoid, with few areas undergoing mineralisation. Areas of chondroid and fibrous tissue were also evident. Stroma was fibro-cellular, few with high vascularity. Areas of hemorrhage and necrosis were also evident in few of the lesions. The common finding in majority of them was the presence of osteoclast like giant cells. Depending upon predominant secretory material, nine of them are sub divided as osteogenic osteosarcoma (69\%) and three of them as chondroblastic osteosarcoma (23\%) and one belonging to fibroblastic variant (8\%).

\section{DISCUSSION}

Osteosarcomas are very rare malignant mesenchymal tumors occurring in the jaws., ${ }^{3,4}$ These lesions commonly seen in fourth decade, though it is reported with a wide age range. ${ }^{10}$ OS of long bones affects mainly adolescents and young adults, where as gnathic OS seen mainly in middle age (third to fourth decade of life). ${ }^{11-16}$ However, the peculiarity in our sample was that OS is mostly seen in young adults (second decade). Similar age group was afftected in an Iranian study. ${ }^{5}$ 
Table 1. Demographic features of Osteosarcomas.

\begin{tabular}{|c|c|c|c|c|c|c|c|}
\hline SI No & Age (years) & Sex & Site & Clinical features & Radiographic features & Histopathology & Treatment \\
\hline 1 & 45 & $\mathrm{M}$ & $\begin{array}{l}\text { Maxilla - } \\
\text { left side }\end{array}$ & $\begin{array}{l}\text { Swelling since } 1 \\
\text { month }\end{array}$ & $\begin{array}{l}\text { Unilocular radiolucency, } \\
\text { Resorption wrt 24, 25, } 26\end{array}$ & Chondroblastic & $\begin{array}{l}\text { Excision with } \\
\text { radiotherapy }\end{array}$ \\
\hline 2 & 17 & $\mathrm{~F}$ & $\begin{array}{l}\text { Mandible- } \\
\text { right side }\end{array}$ & $\begin{array}{l}\text { Pain and swelling } \\
\text { since } 5 \text { months }\end{array}$ & $\begin{array}{l}\text { Mixed opacity and } \\
\text { lucency, osteophytes }\end{array}$ & Osteogenic & $\begin{array}{l}\text { Excision with } \\
\text { radiotherapy }\end{array}$ \\
\hline 3 & 50 & $\mathrm{~F}$ & $\begin{array}{l}\text { Mandible } \\
\text { - left side }\end{array}$ & $\begin{array}{l}\text { Swelling, pain, } \\
\text { paresthesia }\end{array}$ & $\begin{array}{l}\text { Mixed opacity and } \\
\text { lucency, resorption wrt } \\
33-36\end{array}$ & Osteogenic & $\begin{array}{l}\text { Excision with } \\
\text { radiotherapy }\end{array}$ \\
\hline 4 & 53 & $\mathrm{M}$ & $\begin{array}{l}\text { Maxilla - } \\
\text { left }\end{array}$ & $\begin{array}{l}\text { Swelling since } 3 \\
\text { years }\end{array}$ & $\begin{array}{l}\text { Mixed opacity and } \\
\text { lucency, resorption wrt } \\
23-28\end{array}$ & Chondroblastic & $\begin{array}{l}\text { Excision with } \\
\text { radiotherapy }\end{array}$ \\
\hline 5 & 30 & $\mathrm{~F}$ & $\begin{array}{l}\text { Mandible } \\
\text { - right } \\
\text { side }\end{array}$ & $\begin{array}{l}\text { Swelling and pain } \\
\text { since } 3 \text { months }\end{array}$ & $\begin{array}{l}\text { Mixed opacity and lu- } \\
\text { cency with discontinuous } \\
\text { lower border }\end{array}$ & Fibroblastic & $\begin{array}{l}\text { Excision with } \\
\text { radiotherapy }\end{array}$ \\
\hline 6 & 45 & $\mathrm{M}$ & $\begin{array}{l}\text { Maxilla - } \\
\text { right }\end{array}$ & $\begin{array}{l}\text { Swelling since } 6-8 \\
\text { months }\end{array}$ & $\begin{array}{l}\text { Mixed opacity and } \\
\text { lucency, extension into } \\
\text { lateral wall of the orbit, } \\
\text { maxillary sinus and naso- } \\
\text { ethmoidal complex }\end{array}$ & $\begin{array}{l}\text { Osteogenic (Epithe- } \\
\text { loid) }\end{array}$ & $\begin{array}{l}\text { Excision with } \\
\text { radiotherapy }\end{array}$ \\
\hline 7 & 27 & $\mathrm{M}$ & $\begin{array}{l}\text { Maxilla - } \\
\text { right side }\end{array}$ & $\begin{array}{l}\text { Swelling (history } \\
\text { of retinoblastoma } \\
\text { in the same } \\
\text { region) }\end{array}$ & $\begin{array}{l}\text { Mixed opacity and } \\
\text { lucency with obliteration } \\
\text { of right orbit }\end{array}$ & Osteogenic & $\begin{array}{l}\text { Excision with } \\
\text { radiotherapy }\end{array}$ \\
\hline 8 & 70 & $\mathrm{M}$ & $\begin{array}{l}\text { Maxilla - } \\
\text { Left }\end{array}$ & $\begin{array}{l}\text { Swelling since } 1 \\
\text { year }\end{array}$ & Diffuse radiolucency & Osteogenic & $\begin{array}{l}\text { Excision with } \\
\text { radiotherapy }\end{array}$ \\
\hline 9 & 30 & $M$ & $\begin{array}{l}\text { Maxilla - } \\
\text { right }\end{array}$ & $\begin{array}{l}\text { Swelling and pain } \\
\text { since } 3-4 \text { months }\end{array}$ & Diffuse radiolucency & Chondroblastic & $\begin{array}{l}\text { Excision with } \\
\text { radiotherapy }\end{array}$ \\
\hline 10 & 40 & $\mathrm{~F}$ & $\begin{array}{l}\text { Maxilla- } \\
\text { left }\end{array}$ & $\begin{array}{l}\text { Swelling and pain } \\
\text { since } 1 \text { month }\end{array}$ & $\begin{array}{l}\text { Diffuse opacification } \\
\text { involving right maxillary } \\
\text { sinus }\end{array}$ & Osteogenic & $\begin{array}{l}\text { Excision with } \\
\text { radiotherapy }\end{array}$ \\
\hline 11 & 22 & $\mathrm{M}$ & $\begin{array}{l}\text { Mandible } \\
\text {-left }\end{array}$ & Swelling and pain & $\begin{array}{l}\text { Mixed opacity and } \\
\text { lucency, ground glass ap- } \\
\text { pearance, extending till } \\
\text { angle of the mandible }\end{array}$ & Osteogenic & $\begin{array}{l}\text { Excision with } \\
\text { radiotherapy }\end{array}$ \\
\hline 12 & 24 & $\mathrm{~F}$ & $\begin{array}{l}\text { Maxilla - } \\
\text { Right }\end{array}$ & $\begin{array}{l}\text { Swelling since } 3 \\
\text { months }\end{array}$ & $\begin{array}{l}\text { Mixed opacity and } \\
\text { lucency }\end{array}$ & Osteogenic & $\begin{array}{l}\text { Excision with } \\
\text { radiotherapy }\end{array}$ \\
\hline 13 & 60 & $\mathrm{~F}$ & $\begin{array}{l}\text { Maxilla - } \\
\text { left }\end{array}$ & $\begin{array}{l}\text { Swelling and pain } \\
\text { since } 6 \text { months }\end{array}$ & $\begin{array}{l}\text { Diffuse lucency extend- } \\
\text { ing till tubersity }\end{array}$ & Osteogenic & $\begin{array}{l}\text { Excision with } \\
\text { radiotherapy }\end{array}$ \\
\hline
\end{tabular}

There was slight male predilection in the present study as was evident in a Srilankan data. ${ }^{6}$ Most of earlier work has shown a definite male predominance. ${ }^{5,7,9}$ On the other hand, no sex predilection was evident in a research work conducted by Jasnau $S$ et al. ${ }^{8}$ In only one analysis, female predilection was seen. ${ }^{4}$ According to previous results, it is clearly evident, that OS are often seen in mandible compared to that of maxilla. ${ }^{4-9}$ However, in the present sample, maxilla is frequently involved which is a very uncommon finding.

Painfull swelling and paresthesia is a typical complaint of the patients in gnathic OS. ${ }^{3}$ However, swelling was the complaint in all the cases here, with pain in $60 \%$ of the time and paresthesia in only one patient.

Interesting finding here our patients, that many of them had a history of extraction before the onset of the lesion. Such a finding is not reported before. Radiographically, lesion can be osteolytic, osteoblastic or mixture of the two with poorly defined margins. ${ }^{3}$ In the present data also, most of them were mixed lesions with both lucency and

opacity with irregular borders.

Microscopically, theysaythatmost common subtypeis mixed one. ${ }^{5-9}$ However, the opinion is varied in this regard. Most of the time it will be osteogenic osteosarcoma, as seen in the present population. ${ }^{4-6}$ In one of the groups, chondroblastic variant is widespread followed by fibroblastic. ${ }^{7}$ In this African population, only $17 \%$ of the total number of cases were showing osteogenic osteosarcoma, which is a rare phenomenon. This histological subclassification is clinically significant as chondroblastic and fibroblastic has a better prognosis compared to osteogenic OS. ${ }^{17,18}$

OS of jaws rarely metastasizes to other parts of the body as seen in the present patients where there was no metastasis. ${ }^{11-13}$ With respect to treatment, controversy still exists regarding the combination of surgery, radiotherapy and chemotherapy. ${ }^{19-21}$ However, in all 13 cases of OS, here were treated with a combination of surgery and radiotherapy. 


\section{CONCLUSION}

The outcome of this study suggests that a very few osteosarcomas reported in this area ( $0.2 \%$ of total biopsies). Most of the subtype belongs to osteogenic osteosarcoma
(70\%). The common age group is young age (3rd decade) with slight male predilection. Interesting thing in our study is many cases had a history of extraction before the present lesion.

\section{REFERENCES}

1. Schajowicz F. Histological typing of tumors of bone; WHO international histological typing of tumors.Springer-Verlag: Berlin.1993

2. Garrington GE, Scofield HH, Cornyn J, Hooker SP. Osteosarcoma of the jaws: analysis of 56 cases. Cancer 1967;20:377-391.

3. Chindia ML. Osteosarcoma of the jaw bones. Oral Oncology 2001;37:545-547.

4. Bennett JH, Thomas G, Evans AW, Speight PM. Osteosarcoma of the jaws: a 30-year retrospective review. Oral Surg Oral Med Oral Pathol Oral Radiol Endod 2000;90:323-33.

5. Aziz T, Motamedi M, Jafari SM. Gnathic Osteosarcomas: a 10-year multi-center demographic study. Indian J Cancer 2009;46:231-33.

6. Nissanka EH, Amaratunge EAPD, Tilakaratne WM. Clinicopathological analysis of osteosarcoma of jaw bones. Oral Diseases 2007;13:82-87.

7. Ogunlewe MO, Ajayi OF, Adeyemo WL, Ladeinde AL, James O. Osteogenic Sarcoma of the jaw bones: A single institution experience over a 21-year period. Oral Surg Oral Med Oral Pathol Oral Radiol Endod 2006;101:76-81.

8. Jasnau S, Meyer U, Potratz J, Jundt G, Kevric M, Joos UK et.al. Craniofacial osteosarcoma: Experience of the co-operative German-Austrian-Swiss osteosarcoma study group. Oral Oncology 2008;44:286-294.

9. Clark JL, Unni KK, Dahlin DC, Devine KD. Osteosarcoma of the jaw. Cancer 1983;51:2311-2316.

10. Caron AS, Hajdu SI, Strong EW. Osteogenic sarcoma of the facial and cranial bones. Am J Surg 1971;122:719-25.

11. Mark RJ, Sercarz JA, Tran L, Dodd LG, Selch M, Calcaterra TC. Osteosarcoma of head and neck. Arch Otolaryngol Head Neck Surg 1991;117:761-6.

12. August $M$, Magennis $P$, Dewitt $D$. Osteogenic sarcomas of the jaws: factors influencing prognosis. Int J Oral Maxillofac Surg 1997;26:198204.

13. Delgado R, Maafs E, Alfeiran A. Osteosarcoma of the jaw. Head Neck 1994;16:246-52

14. Tran LM, Mark R, Meier MD,Calcaterra TC, Parker RG. Sarcomas of the head and neck: prognostic factors and treatment strategies. Cancer 1992;70:169-77

15. Roca AN, Smith JL, Jing BS. Osteosarcoma and parosteal osteogenic osteogenic sarcoma of the maxilla and mandible: study of 20 cases. Am J Clin Pathol 1970;54:625.

16. Bertoni F, Dallera P, Bacchini P. The Instituto Rizzoli Beretta experience with osteosarcoma of the jaw. Cancer 1991;68:1555.

17. Dorfman HD, Czerniak B. Bone cancers. Cancer 1995;75:203-10

18. Saito K, Unni KK, Wallan PC, Lund BA. Chondrosarcoma of the jaws and facial bones. Cancer 1995;76:1550-8.

19. Forteza G, Colmenero B, Lopez-Barea F. Osteogenic sarcoma of the maxilla and mandible. Oral Surg Oral Med Oral Pathol 1986;62:179.

20. Li Volsi VA. Osteogenic sarcoma of the maxilla. Arch Otolaryngol Head Neck Surg 1977;103:485.

21. Windle-Taylor PC. Osteosarcoma of the upper jaw. J Maxillofacial Surg 1977; 5:62. 